\title{
Pengetahuan dan Sikap tentang Perilaku Merokok pada Remaja
}

\author{
Julaecha $^{1}$, Ajeng Galuh Wuryandari ${ }^{2}$ \\ ${ }^{1}$ Prodi D III Kebidanan STIKes Baiturrahim \\ ${ }^{2}$ Politeknik Kesehatan Kementrian Kesehatan Jambi \\ Email:echa.mamee@gmail.com
}

Submitted : 27/12/2020

Accepted: 10/09/2021

Published: 15/09/2021

\begin{abstract}
Smoking is a health problem in Indonesia and one of the main factors of several chronic diseases that can lead to death, although many smokers are aware and admit that smoking can lead to cancer. WHO estimates that the number of smokers in Indonesia in 2025 will increase to 90 million people, or $45 \%$ of the total population. Some adolescents think that smoking is a need to relax or other reasons that make smoking commonplace. The proportion of smoking among people aged $\geq 10$ years in Indonesia with smoking behavior every day is $24.3 \%$ and occasional smoking is $4.6 \%$. This study aims to determine the level of knowledge, attitudes and smoking behavior in adolescents. The research method used is correlational with cross sectional approach. The population in this study were students and female students at SMKN Kota Jambi, the sampling technique with accidental sampling was 49 people. The instrument used was a questionnaire. The collected data were analyzed by univariate and bivariate and statistical tests were performed using the ch-square test. The results showed that most of the respondents had good knowledge of 57.1\%, a positive attitude of $59.1 \%$ and the majority of adolescents did not smoke $63.2 \%$. The statistical test results showed no significant relationship between knowledge and smoking behavior $(P>0.005)$ but there was a significant relationship between attitude and smoking behavior in adolescents $(P<0.005)$. It is hoped that the school will implement a smoking-free area and put up a warning poster for the dangers of smoking in the school environment and carry out continuous monitoring and evaluation. Keywords: attitudes, knowledge, smoking behaviour, teenager
\end{abstract}

\begin{abstract}
Abstrak
Merokok merupakan permasalahan kesehatan di Indonesia dan salah satu faktor utama dari beberapa penyakit kronis yang dapat mengakibatkan kematian, meskipun banyak perokok yang menyadari dan mengakui bahwa merokok dapat memicu timbulnya kanker. WHO memperkirakan jumlah perokok di Indonesia tahun 2025 akan meningkat menjadi 90 juta orang, atau $45 \%$ dari jumlah populasi Sebagian remaja menganggap bahwa merokok adalah suatu kebutuhan untuk santai atau berbagai alasan lain yang membuat merokok adalah hal yang biasa. Proporsi Merokok pada Penduduk Umur $\geq 10$ Tahun di Indonesia dengan perilaku merokok setiap hari sebesar 24,3\% dan merokok kadang-kadang sebesar 4,6\%. Penelitian ini bertujuan untuk mengetahui tingkat pengetahuan, sikap dan perilaku merokok pada remaja. Metode penelitian yang digunakan yaitu korelasional dengan pendekatan cross sectional. Populasi pada penelitian ini adalah siswa dan siswi di SMKN Kota Jambi, Tehnik pengambilan sampel dengan accidental sampling sebanyak 49 orang. Instrumen yang digunakan yaitu kuesioner. Data yang terkumpul di analisis secara univariat dan bivariat dan di lakukan uji statistik menggunakan uji ch-square. Hasil penelitian menunjukkan sebagian besar responden memiliki pengetahuan baik $57,1 \%$, sikap positif $59,1 \%$ dan mayoritas remaja tidak merokok $63,2 \%$. Hasil uji statistik menunjukkan tidak terdapat hubungan bermakna antara pengetahuan dengan perilaku merokok $(\mathrm{P}>0.005)$ namun terdapat hubungan bermakna antara sikap dengan perilaku merokok pada remaja $(\mathrm{P}<0.005)$. diharapkan pihak Sekolah menerapkan kawasan bebas merokok serta memasang poster peringatan bahaya merokok dilingkungan sekolah dan dilakukan monitoring dan evaluasi secara kontinyu.
\end{abstract}

Kata Kunci: pengetahuan, perilaku merokok, remaja, sikap 


\section{PENDAHULUAN}

Merokok merupakan salah satu perilaku yang berbahaya bagi kesehatan, namun perilaku ini masih sulit untuk dihilangkan. Tingkat konsumsi rokok di Indonesia justru menunjukkan angka yang relatif lebih tinggi dibandingkan dengan negara-negara lain di Asia tenggara. World Health Organization (WHO) mencatat saat ini $36 \%$ penduduk Indonesia merokok, atau lebih dari 60 juta orang. WHO juga memperkirakan jumlah perokok di Indonesia tahun 2025 akan meningkat menjadi 90 juta orang, atau $45 \%$ dari jumlah populasi (Larasati, 2016). Indonesia sebagai negara terbesar ketiga didunia dengan persentase perokok berat terbanyak setelah Cina dan India. Bahkan Indonesia mendapat penghargaan Asthray Award atau negara keranjang nikotin (Fatonah, 2016).

Tembakau membunuh lebih dari 7 juta orang setiap tahun. Lebih dari 6 juta kematian tersebut akibat dari penggunaan tembakau langsung dan 890.000 orang akibat terpapar oleh asap rokok (perokok pasif) dan berdasarkan hasil Riskesdas tahun 2018prevalensi merokok $9,1 \%$ yaitu pada penduduk umur 10-18 tahun. Selain itu proporsi konsumsi tembakau pada penduduk Indonesia usia 15 tahun ke atas adalah pria $62,9 \%$ dan wanita $4,8 \%$ ( Riskesdas 2018)

Proporsi Merokok pada Penduduk Umur $\geq 10$ Tahun di Indonesia dengan perilaku merokok setiap hari sebesar $24,3 \%$ dan merokok kadang-kadang sebesar 4,6\%. di Provinsi Jambi jumlah perokok setiap hari $21,5 \%$ dan kadangkadang merokok sebesar (3,8\%). Proporsi merokok pada usia remaja cukup tinggi yaitu usia 10-14 tahun yang perokok setiap hari sebesar $0,7 \%$ dan perokok kadang-kadang sebesar $1,4 \%$ sedangkan pada usia 15-19 tahun yang perokok setiap hari sebesar $12,7 \%$ dan perokok kadangkadang sebesar 6,9\% (Kemenkes RI, 2018).
Data di Kota Jambi pada tahun 2018, jumlah remaja perokok pada lakilaki usia 10-14 tahun sebanyak 535 orang, usia 15-18 tahun sebanyak 1.198 orang dan pada remaja perempuan usia 10-14 tahun sebanyak 20 orang dan usia 15-18 tahun sebanyak 68 orang. (Dinkes Kota Jambi, 2018). Kementrian kesehatan RI menyatakan bahwa beban ekonomi dan sosial yang ditimbulkan akibat mengkonsumsi rokok semakin meningkat. Belum lagi beban yang ditanggung oleh keluarga perokok dan pemerintah untuk menanggung biaya sakit akibat penyakit yang disebabkan oleh rokok.

Dampak jangka panjang konsumsi rokok merupakan salah satu faktor resiko utama terjadinya berbagai penyakit tidak menular seperti penyakit jantung koroner, stroke, kanker, penyakit paru kronik dan diabetes melitus yang merupakan penyebab kematian utama di dunia, termasuk Indonesia. Saat ini, lebih dari 60 juta penduduk Indonesia adalah perokok aktif. Jumlah ini terus bertambah dari tahun ke tahun dan menempatkan Indonesia ke peringkat ketiga dengan jumlah perokok aktif tertinggi di dunia setelah China dan India (Kemenkes RI, 2013).

Upaya yang dilakukan pemerintah saat ini sejalan dengan pengendalian tembakau dari WHO, di Indonesia yaitu menerapkan Kebijakan Kawasan Tanpa Rokok (KTR) sebagai strategi intervensi utama pengendalian rokok. Kebijakan ini diatur dalam Peraturan Bersama Menteri Kesehatan dan Menteri Dalam Negeri, tentang Pedoman pelaksanaan asap rokok (Kemenkes RI, 2013). Sasaran ke 3 SDGs yakni penurunan sepertiga kematian dini akibat penyakit tidak menular pada 2030 dimana konsumsi rokok menjadi faktor risiko utama kematian dini, maka kebijakan pengendalian tembakau sangat diperlukan, mengingat selain merusak kesehatan meluasnya penghisap rokok terutama di kalangan siswa dan remaja berdampak 
negatif bagi pencapaian pembangunan berkelanjutan (SDGs) 2030. (Kemendikbud, 2018). Berdasarkan uraian latar belakang diatas penulis ingin mengetahui tingkat pengetahuan, sikap dan perilaku merokok pada remaja di Kota Jambi

\section{METODE PELAKSANAAN}

Penelitian inimerupakan penelitian korelasional yaitu penelitian yang bertujuan untuk mengetahui hubungan korelatif antara variabel dependen dan independen dengan desain cross sectional. Penelitian ini dilaksanakan di SMK Kota Jambi populasi pada penelitian ini adalah seluruh siswa dan siswi SMKN Kota Jambi, sampel pada penelitian ini adalah 49 orang dengan tehnik pengambian sampel accidental sampling. Instrumen yang digunakan dalam penelitian ini adalah kuesioner. Data yang terkumpul di analisis secara univariat dan bivariat dengan menggunakan uji Statistik Chi-Square.

\begin{tabular}{cccc} 
HASIL DAN PEMBAHASAN \\
Tabel $\begin{array}{c}\text { 1. Gambaran umur } \\
\text { pengetahuan, sikap dan } \\
\text { merokok }\end{array}$ & & & \\
\hline Variabel & & $\mathbf{n}=\mathbf{4 9}$ & $\mathbf{\%}$ \\
\hline Umur & 15 th & 16 & 32,6 \\
& 16 th & 23 & 46,9 \\
& 17 th & 10 & 20,4 \\
\hline Pengetahuan & & & \\
& Kurang & 21 & 42,8 \\
& Baik & 28 & 57,1 \\
\hline
\end{tabular}

\begin{tabular}{cccc}
\hline Sikap & & & \\
& Negatif & 20 & 40,8 \\
& Positif & 29 & 59,1 \\
\hline Perilaku & & & \\
Merokok & Tidak & 31 & 63,2 \\
& Ya & 18 & 36.7 \\
\hline
\end{tabular}

Berdasarkan tabel 1 menunjukkan bahwa sebagian besar responden berusia 16 tahun sebanyak 23 orang (46,9\%), memiliki pengetahuan baik tentang bahaya merokok sebanyak 28 orang $(57,1 \%)$, sebagian besar responden memiliki sikap positif terhadap dampak merokok 29 orang $(59,1, \%)$ dan 31 orang $(63,2 \%)$ responden tidak merokok.

Tabel 2. Hubungan Pengetahuan dengan perilaku merokok pada remaja

\begin{tabular}{lccccc}
\hline \multirow{2}{*}{ Pengetahuan } & \multicolumn{3}{c}{ Perilaku merokok } & \multirow{2}{*}{ Ya } & \multicolumn{2}{c}{ Tidak } & P Value \\
\cline { 2 - 5 } & n & \% & n & \% & \\
\hline Kurang & 8 & 38,0 & 13 & 61,9 & $>0.05$ \\
Baik & 10 & 35,7 & 18 & 64,2 & \\
\hline
\end{tabular}

Tabel 2 menunjukkan bahwahasiluji statitsik dengan chi square nilai $\mathrm{p}$ value $>$ 0,005 yang berarti tidak terdapat hubungan bermakna antara pengetahuan dengan perilaku merokok pada remaja.

Tabel 3. Hubungan Sikap dengan perilaku merokok pada remaja

\begin{tabular}{cccccc}
\hline \multirow{2}{*}{ Sikap } & \multicolumn{4}{c}{ Perilaku merokok } & \\
\cline { 2 - 5 } & & Ya & \multicolumn{2}{c}{ Tidak } & PValue \\
& n & $\%$ & n & \% & \\
\hline Negatif & 10 & 20,4 & 10 & 20,4 & $<0,05$ \\
Positif & 8 & 16,3 & 21 & 42,8 & \\
\hline
\end{tabular}

Tabel 3 menunjukkan bahwahasil uji statitsik dengan chi square nilai $p$ value < 0,005 yang berarti terdapat hubungan bermakna antara sikap dengan perilaku merokok.

Mayoritas responden pada penelitan ini berusia 16 tahun sebanyak23 orang (46,9\%)merupakan remaja akhir, pada usia ini remaja mempunyai aspek psikis dan fisik yang mulai stabil, berfikir realistissehingga dapat menyelesaikan masalah dengan baik. Namun pada penelitian ini masih ada 18 orang (36,7\%) remaja yang merokok. Perilaku merokok pada usia remaja akhir kemungkinan remaja sudah merokok pada usia remaja awal 
karena pada masa ini psikologis masih labil, mudah dipengaruhi oleh lingkungan,merupakan masa peralihan dari anak-anak dan dewasa, cenderung mencari identitas diri.

Hasil penelitian ini menunjukkan bahwa mayoritas responden memiliki pengetahuan baik tentang bahaya merokok sebanyak 28 orang $(57,1 \%)$ hal ini karena banyaknya dan mudahnya informasi tentang bahaya merokok diperoleh oleh remaja seperti iklan tentang bahaya merokok, informasi yang ada di media cetak maupun elektronik menyebabkan responden memiliki pengetahuan yang baik, selain itu pengetahuan responden juga di dapatkan dari orang tua yang melarang anaknya merokok dengan alasan yang bermacam- macam, pemahaman yang diberikan orang tua ini mempengaruhi pengetahuan responden.

Menurut Notoatmodjo pengetahuan merupakan sejumlah fakta dan teori yang memungkinkan dapat memecahkan masalah yang dihadapi, pengetahuan tersebut dapat diperoleh dari pengalaman langsung maupun pengalaman orang lain. Tahu memiliki arti mengingat sesuatu materi yang telah dipelajari, termasuk ke dalam pengetahuan tingkat ini adalah mengingat kembali terhadap yang dipelajari atau rangsangan yang diterima. Salah satu faktor yang dapat mempengaruhi pengetahuan seseorang yaitu informasi yang diperoleh dari berbagai sumber akan mempengaruhi tingkat pengetahuan seseorang. Semakin banyak informasi yang masuk maka akan semakin banyak pengetahuan yang didapatkan sehingga seseorang akan mampu menunjukkan perbuatan nyata dalam hal ini tidak melakukan tindakan merokok. (Notoatmodjo 2007)

Hasil penelitian ini tidak sejalan dengan teori dimana masih ada responden yang memiliki pengetahuan baik namun tetap merokok sebanyak 10 orang $(35,7 \%)$ dan berdasarkan hasil uji statitik tidak terdapat hubungan bermakna antara pengetahuan dengan perilaku merokok menurut asumsi peneliti hal ini dimungkinkan karena faktor lingkungan, teman yang dapat mempengaruhi perilaku merokok pada remaja, dan remaja sudah memulai merokok pada usia remaja awal dimana kondisi psikisnya masih labil.

Hasil penelitian ini sejalan dengan penelitian Dian P (2019) tentang tingkat pengetahuan dan sikap tentang perilaku merokok pada remaja di SMKN 3 Ambon menyatakan bahwa tidak terdapat hubungan antara pengetahuan dengan perilaku merokok pada remaja dan didukung oleh penelitianMuhammad Rachmat tentang perilaku merokok remaja Sekolah Menengah Pertama menyatakan bahwa tidak terdapat hubungan antara pengetahuan dengan perilaku merokok.

Hasil penelitian ini tidak sejalan dengan penelitian Hermina Husein tentang Pengetahuan dengan perilaku merokok remaja di Sulawesi Selatan menyatak bahwa terdapat hubungan bermakna antara pengetahuan dengan perilaku merokok pada remaja. pengetahuan sangat berpengaruh karena pengetahuan menentukan sikap dan tindakan remaja terhadap perilaku merokok (Alamsyah, 2009). Menurut Lawrence Green juga menyatakan bahwa salah satu faktor yang menentukan perilaku seseorang yaitu faktor predisposisi, diantaranya adalah pengetahuan. Pengetahuan adalah hasil penginderaan manusia atau hasil tahu seseorang terhadap objek melalui indera yang dimilikinya (Notoatmodjo, 2007).

Sikap merupakan reaksi atau respon yang masih tertutup dari seseorang terhadap stimulus atau objek. Sikap disebut juga suatu kesiapan bertindak untuk motif tertentu. Sesuai dengan hasil penelitian ini menunjukkan bahwa masih ada remaja yang memiliki sikap positif terhadap bahaya atau dampak merokok tetapi tetap merokok hal ini dimungkinkan karena banyak faktor yang mempengaruhi sikap antara lain: pengalaman, pengaruh orang 
sekitar yang di anggap penting, media massa, lembaga pendidikan, agama serta pengaruh faktor emosional. (Notoatmodjo, 2007).

Hasil penelitian ini menunjukkan mayoritas responden memiliki sikap positif sebanyak 29 orang $(59,1 \%)$ terhadap bahaya/dampak merokok. Perilaku tidak hanya di pengaruhi oleh kognitif saja namun juga dipengaruhi oleh afektif dan psikomotor. Pemberian informasi tentang bahaya merokok perlu disebarluaskan untuk merubah sikap seseorang. Berdasarkan hasil penelitian ini terdapat hubungan bermkna antara sikap dengan perilaku merokok pada remaja.

Hasil penelitian ini sejalan dengan penelitian Muhammad R (2013) tentang Perilaku merokok remaja sekolah menengah pertama di Suarakarta menyatakan bahwa terdapat hubungan anatara sikap dengan perilaku merokok pada remaja pada pelajar SMP di Surakarta. (Muhammad R, 2013)

\section{SIMPULAN}

Simpulan dari penelitian tentang pengetahuan dan sikap remaja terhadap perilaku merokok menunjukkan pengetahuan responden sebagian besar baik serta memiliki sikap positif dan sebagian besar responden tidak merokok. Berdasarkan hasil uji statistik antara pengetahuan dengan perilaku merokok tidak terdapat hubungan bermakna dengan nilai $\mathrm{p}$ value $>0,005$ dan hasil uji statistik antara sikap dengan perilaku merokok terdapat hubungan bermakna dengan nilai $\mathrm{p}$ value $<0,005$.

\section{SARAN}

Diharapkan Pihak sekolah melibatkan orang tua dalam upaya mencegah dan mengintervensi perilaku merokok pada remaja lebih intensif, membuat informasi-informasi terkait larangan merokok dengan gambar-gambar yang di pasang dilingkungan sekolah serta melakukan monitoring dan evaluasi secara kontinyu serta bekerja sama dengan pihak puskesmas untuk sosilaisasi dan pendampingan.

\section{DAFTAR PUSTAKA}

Alamsyah, R.M. Faktor-faktor yang mempengaruhi kebiasaan merokok dan hubungannya dengan status penyakit periodontal remaja kota medan" Tesis S2 Universitas Sumatra Utara. Medan: 2009.

BPS.Survey Kesejahteraan Nasional/ Susenas 2001. Badan Pusat Statistik (BPS) Jakarta. 2001

Dian Petrici S, Alessandra Saija, Nathalie E Kailola. Tingkat pengetahuan dan Sikap Responden tentang perilaku merokok pada remaja di SMKN 3 Ambon Tahun 2019. PAMERI Volume 2, Nomor 1 April 2020, ISSN 2686-5165 https://ojs3.unpatti.ac.id

Hermina Husein, Maria Kurnia Menga Pengetahuan dengan Perilaku Merokok Remaja. Jurnal Ilmiah Kesehatan, Vol 1, No. 12019

Kementrian Kesehatan Republik Indonesia. Riset Kesehatan Dasar (RISKESDAS) 2018. Jakarta, 2018.

Kemenkes RI. 2013. Iiniilah 4 Bahaya Merokok Bagii Kesehatan Tubuh.www.Kemkes.go.id

Kemenkes RI 2015. Pusat Data dan Informasi (Infodatin 2015) Perilaku merokok Masyarakat Indonesia berdasarkan Riskesdas 2007 dan 2013.

Kemendikbud2018 . Rokok Hambat $\begin{array}{lll}\text { Capaian } & \text { SDGs }\end{array}$ https.//Kemendikbud.RI

Muhammad Rachmat, Ridwan Mochtar ThahaMuhammad Syafar. Perilaku Merokok Remaja Sekolah Menengah Pertama. Jurnal kesehatan Masyarakat Nasional vol 7 no 11 juni 2013 
Nasution, I.K. Perilaku Merokok pada Remaja. Medan: Universitas Sumatra Utara. 2007

Notoatmodjo, Soekidjo. Promosi Kesehatan dan Perilaku Kesehatan. Jakarta: Rineka cipta. 2007

Sulistyawan, Ade. 2013. Faktor-faktor yang berhubungan dengan perilaku merokok kota tangerang selatan tahun 2012.

WHO Tobacco data. 2016 http://www.who.int/media 